Pak. j. sci. ind. res. Ser. B: bio. sci. 2020 63B(2) 105-112

\title{
Preparation and Development of Fig Fruit Jam Blended with Different Level of Apple Pulp
}

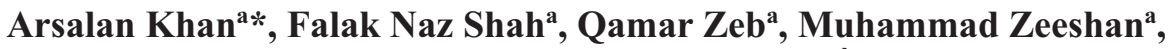 \\ Huzaifa Iqbal ${ }^{\mathrm{a}}$ and Hamid Noor ${ }^{\mathrm{b}}$ \\ ${ }^{a}$ Agriculture Research Institute (ARI) Tarnab, Peshawar \\ ${ }^{\mathrm{b}}$ The University of Agriculture Peshawar, Pakistan
}

(received July 16, 2018; revised November $1^{\text {st }}, 2018$; accepted November 11, 2018)

\begin{abstract}
Fig is familiar in the World as a edible fruit, but technically it is not a fruit it is a container, called a syconium, which is oddly an inside out flower cluster. The present study was conducted to prepare a value-added product form fig fruit blended with apple pulp. The jam was prepared with different combination of fig pulp and apple pulp, 200:200, 250:150, 300:100, 350: 50 and 400:00. The treatments were analyzed physio-chemically and sensory for a total period of 90 days. The statistical results revealed that treatment have a significant $(\mathrm{P}<0.05)$ on physio-chemical and sensory attributes of jam. The physiochemical study revealed that $\mathrm{pH}$, ascorbic acid and non-reducing sugar decreased significantly, while TSS, reducing sugar and $\%$ acidity showed a significant increased during 90 days of storage. In sensory attributes, the control and test samples showed a significant difference in texture, taste and colour. The sensory results indicated that with decreased in the apple pulp the texture properties decreases and the opacity increased. The statistical results showed treatment T1(200:200) was found best among the other treatments followed by T2 (250:150) in chemical and sensory attributes. The new formulated product can serve as a good spread on bread and other etc.
\end{abstract}

Keywords: fig fruit, apple fruit, pulp, jam, storage

\section{Introduction}

Fig (Ficus carica L.) a deciduous tree belonging to the Moraceae family, is one of the earliest cultivated fruit trees. In the northern Mediterranean region, fig trees produce one or two crops per year, depending on the cultivar (Stover et al., 2007). The fig is a delicious, nutritive fruit and has medicinal properties that may reduce the risk of cancer and heart disease. Fig fruit is consumed fresh, dried, preserved, canned and candied. In the Mediterranean region, it is used for alcohol and wine production and in Europe for a fig-coffee preparation. Fresh and dried figs are especially rich in fiber, trace minerals, antioxidant polyphenols, proteins, sugars, organic acids, and volatile compounds that provide a pleasant characteristic aroma. Dried figs can be stored for 6-8 months (Naikwadi et al., 2010). Total crop area under fig in Pakistan is 162 hectares and its production is 741 tons (fresh fruit). In 2007- 08, Pakistan imported dry fig 217 tons which worth Rs. 4.5 million. It is imported from Turkey, Iran and Afghanistan. In 2014-15, fig fruit cultivated under the area of 122 hectares in Pakistan with a production of 459 tons

*Author for correspondence;

E-mail: arsalanakhan.fst@gmail.com
(PARC, 2018), while in Khyber Pakhtunkhwa the area under cultivation of fig fruit is 66 hectares with a production of 419 tons (MINFAL, 2014-2015). The nutrient composition of dried fig is total calories 283, total fat $0.52 \mathrm{~g}$, saturated fat $0.0 \mathrm{~g}$, cholesterol $0.0 \mathrm{mg}$, sodium $12.26 \mathrm{mg}$, potassium $609 \mathrm{mg}$, total carbohydrate $66.16 \mathrm{~g}$, total dietary fibre $12.21 \mathrm{~g}$, insoluble fibre 8.74 $\mathrm{g}$, soluble fibre $3.47 \mathrm{~g}$, sugars $49.0 \mathrm{~g}$, protein $3.14 \mathrm{~g}$, vitamin A $9.76 \mathrm{IU}$, vitamin C $0.68 \mathrm{mg}$, calcium 133.0 $\mathrm{mg}$. Figs are fat free, sodium free and like other plant foods its cholesterol free (Pasman et al., 1997).

Apple (Pyrus domestica L.) is one of the most important tree fruit of the World. The apple was cultivated in Greece around $600 \mathrm{BC}$ or earlier. It is a highly nutritive fruit which is a rich source of sugars $11 \%$, fat $0.4 \%$, protein $0.3 \%$, carbohydrates $14.9 \%$, vitamins and minerals. A $100 \mathrm{~g}$ fresh apple contains, water $84.7 \%$, fiber $0.8 \mathrm{~g}$, carbohydrates $13.9 \mathrm{~g}$, proteins $0.4 \mathrm{~g}$, lipid $0.3 \mathrm{~g}$, ash $0.3 \mathrm{~g}$, vitamin C $8 \mathrm{mg} / 100 \mathrm{~g}$, sodium 0.3 $\mathrm{mg} / 100 \mathrm{~g}$, potassium $145 \mathrm{mg} / 100 \mathrm{~g}$, calcium $7 \mathrm{mg} / 100 \mathrm{~g}$, magnesium $6 \mathrm{mg} / 100 \mathrm{~g}$, iron $480 \mu \mathrm{g} / 100 \mathrm{~g}$, phosphorus $12 \mathrm{mg}$ and iodine $2 \mu \mathrm{g}$ (Hussain, 2001). Due to its high nutritional value, it ranks third in consumption after citrus and banana (Bokhari, 2002). In Pakistan its 
cultivation is limited and restricted to the northern hilly tracts of Punjab and KP, and the Quetta region of Baluchistan. Currently, the apple is grown over an area of 11.13 thousand hectares with a total production of 437.39 thousand tons in Pakistan, (MINFAL, 2014-2015).

Jam is semi-solid mass, which attained from the cooking fruit pulp and sugar followed by acid, pectin, flavours and colouring substances. Jams contain about $68.5 \%$ total soluble substances and $45 \%$ at least fruit pulp, while the (Codex, 2009) revealed that jam should contain more than $65 \%$ total soluble solids in finished product, (Baker et al., 2001). Jam, jellies and marmalade is one simple fruit product prepared from fruit individually or combination of different fruit (Shah et al., 2015).

In Pakistan, fig fruit is consumed either dried or fresh. So, keeping in view the above importance and nutritional value of fig fruit, the presence study is plane to development a value-added product from fig fruit.

\section{Materials and Methods}

Good quality, sound, healthy and mature fig fruit was selected for research work and was procured from the Orchards of Bannu and apple was purchased from the local market of Peshawar. The selected fruits were brought to the Laboratory of Food Science and Technology Section, Agriculture Research Institute (ARI) Tarnab, Peshawar. The fruits were washed with tape water and then pass through pulper machine to extract pulp. The following treatments were made with addition of water, pectin, citric acid, sugar and preservatives (Table 1). The fig pulp, apple pulp and water were first mixed with the sugar and pectin and then cooked, it till the total soluble contents reached to 650 brix. The prepared treatments were filled in glass jar and stored at room temperature for physiochemical and sensory analysis till 90 days.

Chemical used. Sodium benzoate (analytical gradeMerck Germany), sodium hydroxide (analytical grade-

Table. 1. Proposed plan of study

\begin{tabular}{|c|c|c|c|c|c|c|}
\hline $\begin{array}{l}\text { Treat- } \\
\text { ment }\end{array}$ & $\begin{array}{l}\text { fig } \\
\text { pulp }\end{array}$ & $\begin{array}{l}\text { Apple } \\
\text { pulp }\end{array}$ & water & $\begin{array}{l}\text { Pectin \& } \\
\text { citric acid }\end{array}$ & Sugar & Preservatives \\
\hline $\mathrm{T}_{1}$ & $200 \mathrm{~g}$ & $200 \mathrm{~g}$ & $100 \mathrm{~mL}$ & $0.5 \%$ & $500 \mathrm{~g}$ & $0.1 \%$ \\
\hline $\mathrm{T}_{2}$ & $250 \mathrm{~g}$ & $150 \mathrm{~g}$ & $100 \mathrm{~mL}$ & $0.5 \%$ & $500 \mathrm{~g}$ & $0.1 \%$ \\
\hline $\mathrm{T}_{3}$ & $300 \mathrm{~g}$ & $100 \mathrm{~g}$ & $100 \mathrm{~mL}$ & $0.5 \%$ & $500 \mathrm{~g}$ & $0.1 \%$ \\
\hline $\mathrm{T}_{4}$ & $350 \mathrm{~g}$ & $50 \mathrm{~g}$ & $100 \mathrm{~mL}$ & $0.5 \%$ & $500 \mathrm{~g}$ & $0.1 \%$ \\
\hline $\mathrm{T}_{5}$ & $400 \mathrm{~g}$ & $0 \mathrm{~g}$ & $100 \mathrm{~mL}$ & $0.5 \%$ & $500 \mathrm{~g}$ & $0.1 \%$ \\
\hline
\end{tabular}

Sigma), copper sulphate (analytical grade-Merk Germany), oxalic acid (analytical grade- Sigma), 2,6dichloro indophenols (UK, Chemical LTD), potassium hydroxide (analytical grade-Sigma), Methylene blue (Sigma), phenolphthalein (analytical grade-Merk). ascorbic acid (Merk Germany), sodium potassium tartrate (ChemPol England).

Chemical analysis. Acidity, $\mathrm{pH}$, total soluble solids, reducing and non-reducing sugar, ascorbic acid were evaluated through standard methods of (AOAC, 2012).

Sensory analysis. The samples were sensory evaluated for colour, texture, taste and overall acceptability by 10 trained judge's panel. Sensory study was carried out at each 15-day interval for 3-month storage. The evaluation was conceded out by using 9 points hedonic scale of (Larmond, 1977). The results are of scoring rate 1-9 awarded by panel of judges.

Statistical analysis. All the data concerning treatments and storage interval were statistically analyzed by using factorial experiment in completely randomized design and the means were separated by applying least significant difference (LSD) Test at $5 \%$ possibility level as defined by (Steel and Torrie, 1986).

\section{Results and Discussion}

The results of current study indicated that storage period had significant effect on different parameters as described below;

pH. $\mathrm{pH}$ value of the product significantly affects the flavour and perishability. During this study the mean value of $\mathrm{pH}$ of all samples decreased from 3.69 to 3.53. Maximum decrease was recorded in $\mathrm{T}_{3}(3.27 \%)$, while minimum was recorded in $\mathrm{T}_{1}(2.49 \%)$, (Table 2$)$. The decreasing trend in $\mathrm{pH}$ might be due to the hydrolysis of pectic bodies and formation of acidic compound during degradation of sugar contents. The gradual change in mean value of $\mathrm{pH}$ may partly due to their varying composition, observed in mixed fruit jam prepared from water melon flesh part and lemon. The results are in agreement with Ehsan et al. (2003) who observed decrease in $\mathrm{pH}$ of all treatments of mixed jam prepared from watermelon and reported during storage the change in $\mathrm{pH}$ might be due to the change and formation acidic compound during storage of the jam.

Acidity. An acidity is considered one of the physiochemical properties that affect the organoleptic and keeping quality of a product. The experimental result 
reported acidity was gradually increased from 0.7 to 0.9 . Mean value increased from 0.76 to 0.85 . Maximum increased was recorded in $\mathrm{T}_{3}(19.54 \%)$ followed by $\mathrm{T}_{1}$ $(19.15 \%)$ and $\mathrm{T}_{5}(18.89 \%)$, while minimum was recorded in $\mathrm{T}_{2}(18.68 \%)$ (Table 3$)$. Increase in acidity was due to the formation of acids by degradation of polysaccharides and oxidation of reducing sugar or by break down pectic substance and uronic acid reported by (Shah et al., 2015; Hussain, 2008). Similarly, the incline trend in acidity and decline trend in $\mathrm{pH}$ was reported by Ehsan et al.(2003).

Total soluble solid (TSS). The statistical results revealed that treatments and storage intervals had a significant effect on TSS of fig fruit jam blended with apple pulp. Maximum mean values were recorded in $T_{5}$ (69.01) followed by $\mathrm{T}_{4}$ (68.41). Minimum mean value was recorded in $\mathrm{T}_{2}$ (67.69) (Table 4). The increased in total soluble contents of all the samples might be due to conversion of un-soluble polysaccharide to soluble disaccharide in the presence of acid. Similar result was reported by Hussain et al. (2008), during 60 days of storage in grapes fruit marmalade from 70-70.8 brix.
Ehsan et al. (2002) also found an increase in TSS (70 to 70.8 brix) in watermelon and lemon jam. The increase in TSS might be due to hydrolysis of starch into simple sugar (Table 4).

Ascorbic acid. The result of current study also prevailed that storage period had significant effect on ascorbic acid content of different samples. There was a gradual decrease in ascorbic acid of fig fruit jam blended with apple pulp. Minimum percent decrease was observed in $\mathrm{T}_{1}(25.10 \%)$, while maximum was observed in $\mathrm{T}_{5}$ $(40.35 \%)$ (Table 5). Ascorbic acid is the most difficult vitamin to be preserved during storage. It's decreased with the passage of time. This decrease might due to oxidation taking place within the sample as well as enzymatic catalytic reaction taking place within the jam mass during storage. Jawaheer et al., (2003) observed same effects between jam made from guava fruits. Another principal cause of ascorbic acid decrease might be residual oxygen present within the container head space (assuming glass ware was impervious to oxygen) assisted by degrading activities of light. When oxygen is present, AA degradation occurs

Table 2. Effect of storage interval on the $\mathrm{pH}$ of fig fruit jam blended with apple pulp

\begin{tabular}{|c|c|c|c|c|c|c|c|c|c|}
\hline \multirow[t]{3}{*}{ Treat } & \multicolumn{7}{|c|}{ Storage interval } & \multirow[t]{3}{*}{$\%$ Dec. } & \multirow[t]{3}{*}{ Mean } \\
\hline & 0 & 15 & 30 & 45 & 60 & 75 & 90 & & \\
\hline & \multicolumn{7}{|c|}{ pH } & & \\
\hline $\mathrm{T}_{1}$ & 3.62 & 3.61 & 3.59 & 3.58 & 3.56 & 3.55 & 3.53 & 2.49 & $3.58 \mathrm{e}$ \\
\hline $\mathrm{T}_{2}$ & 3.65 & 3.63 & 3.61 & 3.6 & 3.58 & 3.56 & 3.54 & 3.01 & $3.60 \mathrm{~d}$ \\
\hline $\mathrm{T}_{3}$ & 3.67 & 3.65 & 3.63 & 3.61 & 3.59 & 3.57 & 3.55 & 3.27 & $3.61 \mathrm{c}$ \\
\hline $\mathrm{T}_{4}$ & 3.68 & 3.66 & 3.64 & 3.62 & 3.6 & 3.58 & 3.56 & 3.26 & $3.62 b$ \\
\hline $\mathrm{T}_{5}$ & 3.69 & 3.68 & 3.65 & 3.63 & 3.61 & 3.59 & 3.57 & 3.25 & $3.63 \mathrm{a}$ \\
\hline Mean & $3.662 \mathrm{a}$ & $3.646 \mathrm{~b}$ & $3.624 \mathrm{c}$ & $3.608 \mathrm{~d}$ & $3.588 \mathrm{e}$ & $3.57 \mathrm{f}$ & $3.55 \mathrm{~g}$ & & \\
\hline
\end{tabular}

Values with different letters are significantly $(\mathrm{P}<0.05)$ different from each other.

Table 3. Effect of storage interval on the acidity of fig fruit jam blended with apple pulp

\begin{tabular}{|c|c|c|c|c|c|c|c|c|c|}
\hline \multirow[t]{3}{*}{ Treat } & & \multicolumn{6}{|c|}{ Storage interval } & \multirow[t]{3}{*}{ \%Inc } & \multirow[t]{3}{*}{ Mean } \\
\hline & \multirow[t]{2}{*}{0} & 15 & 30 & 45 & 60 & 75 & 90 & & \\
\hline & & & & \multicolumn{4}{|c|}{$\%$ Acidity } & & \\
\hline $\mathrm{T}_{1}$ & 0.70 & 0.79 & 0.82 & 0.85 & 0.88 & 0.91 & 0.94 & 19.15 & $0.85 \mathrm{a}$ \\
\hline $\mathrm{T}_{2}$ & 0.74 & 0.76 & 0.78 & 0.81 & 0.84 & 0.88 & 0.91 & 18.68 & $0.82 \mathrm{~b}$ \\
\hline $\mathrm{T}_{3}$ & 0.7 & 0.72 & 0.74 & 0.77 & 0.8 & 0.83 & 0.87 & 19.54 & $0.78 \mathrm{c}$ \\
\hline $\mathrm{T}_{4}$ & 0.69 & 0.71 & 0.73 & 0.75 & 0.78 & 0.81 & 0.85 & 18.82 & $0.76 \mathrm{~d}$ \\
\hline $\mathrm{T}_{5}$ & 0.73 & 0.75 & 0.77 & 0.8 & 0.83 & 0.87 & 0.9 & 18.89 & $0.81 \mathrm{e}$ \\
\hline Mean & $0.724 \mathrm{~g}$ & $0.746 f$ & $0.768 \mathrm{e}$ & $0.796 \mathrm{~d}$ & $0.826 \mathrm{c}$ & $0.86 \mathrm{~b}$ & $0.89 a$ & & \\
\hline
\end{tabular}

Values with different letters are significantly $(\mathrm{P}<0.05)$ different from each other. 
simultaneously by oxidative and anaerobic mechanisms, the latter pathway being slower than the oxidative one Rojas and Gerschenson (2001). The oxidative degradation of AA is related to ascorbinase activity and by indirect degradation through polyphenol oxidase, cytochrome oxidase and peroxidase activity Lee and Kader (2000). During the first two weeks of storage, the predominant effect is that of the oxidation of the AA to L-dehydroascorbic acid (DHA). From that storage time, the anaerobic degradation becomes predominant Wong et al. (1992).

Reducing sugar. The reducing sugar content was recorded in such a manner that maximum percent increase was recorded in $\mathrm{T}_{1}$ (42.63) while minimum was recorded in $\mathrm{T}_{3}$ (34.80). The maximum mean score was recorded for $T_{1}$ (23.55), whereas minimum mean score was recorded for $\mathrm{T}_{3}(21.85)$ (Table 6). Reducing sugar contents of all samples increased with the passage of time. Glucose and fructose contents were also increased in strawberry fruit as recorded by Ruiz-Nieto et al. (1997). The reason for increasing the reducing sugar might be due to the presence of invertase enzymes but invertase enzymes works properly at $4.6 \mathrm{pH}$ and $50{ }^{\circ} \mathrm{C}$ temperature and since the temperature was ambient in this condition, thus making it inadequate for activity of invertase enzyme. The increase in reducing sugar might be due to the inversion of non-reducing sugar to during storage. The inversion of non-reducing sugar was due to the presence of acid along with high temperature speed up the inversion process. These results agreed with Ali (2004) reported increased trend in reducing sugars of strawberry jam for 90 days storage. Similarly, increase in reducing sugar of apricot jam during storage was also observed by Anjum et al. (2000).

Non-reducing sugar. The non-reducing sugar decreased in all treatments. Maximum percent decrease was recorded for $\mathrm{T}_{1}(52.23 \%)$ and minimum was recorded for $\mathrm{T}_{3}(38.38 \%)$. In case of mean value maximum mean was recorded for $\mathrm{T}_{3}(35.62)$ and minimum was recorded for $\mathrm{T}_{1}$ (29.51) (Table. 7). The decreased in non-reducing sugar of apple olive blended jam might be due the inversion of acid. These results are in agreement with Ayub et al. (2010) reported decreasing trend in nonreducing sugars from 44.64 to $32.35 \%$ of strawberry

Table 4. Effect of storage interval on the TSS of fig fruit jam blended with apple pulp

\begin{tabular}{|c|c|c|c|c|c|c|c|c|c|}
\hline \multirow[t]{3}{*}{ Treat } & \multicolumn{7}{|c|}{ Storage interval } & \multirow[t]{3}{*}{$\%$ Inc } & \multirow[t]{3}{*}{ Mean } \\
\hline & 0 & 15 & 30 & 45 & 60 & 75 & 90 & & \\
\hline & \multicolumn{7}{|c|}{ TSS (brix) } & & \\
\hline $\mathrm{T}_{1}$ & 67.1 & 67.2 & 67.5 & 67.9 & 68.3 & 68.6 & 68.9 & 2.61 & $67.93 d$ \\
\hline $\mathrm{T}_{2}$ & 66.8 & 67.1 & 67.4 & 67.7 & 67.9 & 68.2 & 68.7 & 2.77 & $67.69 \mathrm{e}$ \\
\hline $\mathrm{T}_{3}$ & 67.3 & 67.5 & 67.9 & 68.3 & 68.6 & 68.9 & 69.3 & 2.89 & $68.26 \mathrm{c}$ \\
\hline $\mathrm{T}_{4}$ & 67.2 & 67.7 & 68.1 & 68.5 & 68.8 & 69.1 & 69.5 & 3.31 & $68.41 \mathrm{~b}$ \\
\hline $\mathrm{T}_{5}$ & 68.2 & 68.5 & 68.7 & 68.9 & 69.3 & 69.6 & 69.9 & 2.43 & $69.01 \mathrm{a}$ \\
\hline Mean & $67.32 \mathrm{~g}$ & $67.6 \mathrm{f}$ & $67.9 \mathrm{e}$ & $68.26 \mathrm{~d}$ & $68.5 \mathrm{c}$ & $68.8 \mathrm{~b}$ & $69.2 \mathrm{a}$ & & \\
\hline
\end{tabular}

Values with different letters are significantly $(\mathrm{P}<0.05)$ different from each other.

Table 5. Effect of storage interval on the ascorbic acid of fig fruit jam blended with apple pulp

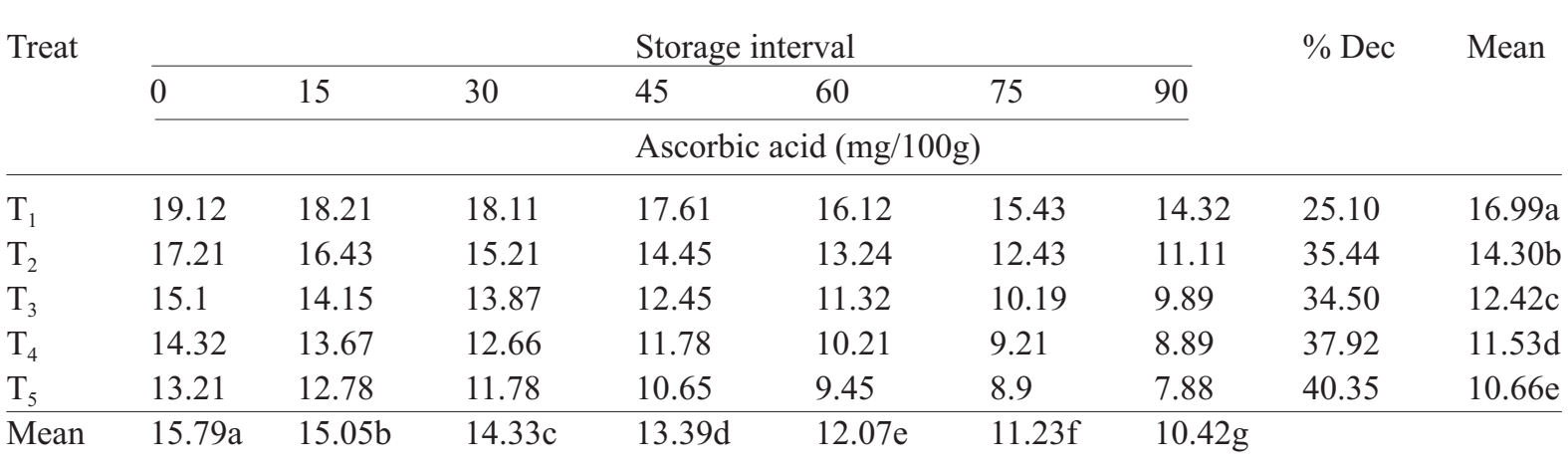

Values with different letters are significantly $(\mathrm{P}<0.05)$ different from each other. 
Table 6. Effect of storage interval on the reducing sugar of fig fruit jam blended with apple pulp

\begin{tabular}{|c|c|c|c|c|c|c|c|c|c|}
\hline \multirow[t]{3}{*}{ Treat } & \multicolumn{7}{|c|}{ Storage interval } & \multirow[t]{3}{*}{$\%$ Dec. } & \multirow[t]{3}{*}{ Mean } \\
\hline & 0 & 15 & 30 & 45 & 60 & 75 & 90 & & \\
\hline & & & & \multicolumn{4}{|c|}{ Reducing sugar (\%) } & & \\
\hline $\mathrm{T}_{1}$ & 17.74 & 19.08 & 20.67 & 22.95 & 25.44 & 28.05 & 30.92 & 42.63 & $23.55 \mathrm{a}$ \\
\hline $\mathrm{T}_{2}$ & 17.71 & 19.43 & 21.37 & 23.15 & 25.37 & 27.62 & 29.86 & 40.69 & $23.50 \mathrm{a}$ \\
\hline $\mathrm{T}_{3}$ & 17.54 & 18.46 & 19.83 & 21.34 & 22.95 & 25.36 & 28.42 & 38.28 & $21.99 \mathrm{~b}$ \\
\hline $\mathrm{T}_{4}$ & 17.56 & 18.69 & 20.12 & 21.83 & 23.55 & 25.48 & 27.65 & 36.49 & $22.13 b$ \\
\hline $\mathrm{T}_{5}$ & 17.65 & 18.72 & 20.04 & 21.55 & 23.13 & 24.82 & 27.07 & 34.80 & $21.85 b$ \\
\hline Mean & $17.64 \mathrm{~g}$ & $18.87 f$ & $20.40 \mathrm{e}$ & $22.16 \mathrm{~d}$ & $24.08 \mathrm{c}$ & $26.26 b$ & $28.78 \mathrm{a}$ & & \\
\hline
\end{tabular}

Values with different letters are significantly $(\mathrm{P}<0.05)$ different from each other.

Table 7. Effect of storage interval on the non-reducing sugar of fig fruit jam blended with apple pulp

\begin{tabular}{|c|c|c|c|c|c|c|c|c|c|}
\hline \multirow[t]{3}{*}{ Treat } & \multicolumn{7}{|c|}{ Storage interval } & \multirow[t]{3}{*}{$\%$ Dec. } & \multirow[t]{3}{*}{ Mean } \\
\hline & 0 & 15 & 30 & 45 & 60 & 75 & 90 & & \\
\hline & \multicolumn{7}{|c|}{ Non-reducing sugar } & & \\
\hline $\mathrm{T}_{1}$ & 40.40 & 36.28 & 33.20 & 29.95 & 25.11 & 22.34 & 19.30 & 52.23 & $29.51 d$ \\
\hline $\mathrm{T}_{2}$ & 42.10 & 39.45 & 36.34 & 33.21 & 29.56 & 25.09 & 23.32 & 44.61 & $32.72 \mathrm{c}$ \\
\hline $\mathrm{T}_{3}$ & 43.20 & 41.46 & 39.50 & 36.71 & 32.29 & 29.56 & 26.62 & 38.38 & $35.62 \mathrm{a}$ \\
\hline $\mathrm{T}_{4}$ & 43.00 & 41.28 & 38.20 & 34.59 & 31.82 & 27.23 & 23.65 & 45.00 & $34.25 b$ \\
\hline $\mathrm{T}_{5}$ & 45.63 & 42.34 & 39.41 & 35.80 & 31.76 & 28.23 & 24.09 & 47.21 & $35.32 \mathrm{a}$ \\
\hline Mean & $42.87 \mathrm{a}$ & $40.16 b$ & $37.33 \mathrm{c}$ & $34.05 \mathrm{~d}$ & $30.11 \mathrm{e}$ & $26.49 f$ & $23.40 \mathrm{~g}$ & & \\
\hline
\end{tabular}

Values with different letters are significantly $(\mathrm{P}<0.05)$ different from each other.

jam for 90 days storage. observed decreased in nonreducing sugar of grape fruit apple marmalade. The maximum decreased recorded 49.41 to $34.85 \%$ and minimum decreased was recorded from 49.50 to $34.60 \%$.

Taste. The data prevailed that storage interval had significantly $(\mathrm{P}<0.05)$ affected the fig fruit jam blended with apple pulp. Mean values of data showed that higher score was recorded for $T_{1}$ (7.39) and lower taste score was recorded for $\mathrm{T}_{5}(6.41)$. Sample $\mathrm{T}_{1}(25.30 \%)$ had lower percent score, while sample $\mathrm{T}_{5}(35.53 \%)$ had higher percent score (Table. 8). Similar result was also found by Chavan and Shaikh (2015). Organic acid and sugar ratio primarily creates a sense of taste which is perceived by specialized taste buds on the tongue. Decrease in taste score might be due to the fluctuation in acids, $\mathrm{pH}$ and sugar/acid ratio. These results are in accordance with Ehsan et al. (2003) reported decreasing trend from 6.2 to 4 during initial and 150 days during storage of watermelon and lemon jam.

Colour. The color of fig fruit jam blended with apple pulp was affected significantly $(\mathrm{P}<0.05)$ during storage
(Table. 9). Maximum percent decrease was recorded for $\mathrm{T}_{5}(37.68 \%)$ and minimum percent decrease was recorded for $\mathrm{T}_{1}(26.58 \%)$. Higher mean value was recorded for $T_{1}$ (6.94) whereas lower mean value was recorded for the sample $\mathrm{T}_{5}(5.74)$. The decrease in the colour of guava product was also noted by Chavan and Shaikh (2015). Changes in colour might be attributed to Millard reaction, enzymatic browning ascorbic acid degradation and polymerization of color pigments (carotenoids and anthocyanin's) with other phenolic compound (Shah et al., 2015). The effect of low storage temperature and freezing techniques on ascorbic acid content and additional qualitative characteristics of Iranian strawberries and affirmed that the storage temperature of 18 and $24{ }^{\circ} \mathrm{C}$ were mostly excellent for preserving the qualitative individually (flavour, texture colour and entirety) of the strawberries Ayub et al. (2010).

Texture. The texture of fig fruit jam blended with apple pulp was affected significantly $(\mathrm{P}<0.05)$ during storage (Table 10). Maximum mean data was recorded for $T_{1}$ 
Table 8. Effect of storage interval on the taste of fig fruit jam blended with apple pulp

\begin{tabular}{|c|c|c|c|c|c|c|c|c|c|}
\hline \multirow[t]{3}{*}{ Treat } & \multicolumn{7}{|c|}{ Storage interval } & \multirow[t]{3}{*}{$\%$ Dec. } & \multirow[t]{3}{*}{ Mean } \\
\hline & 0 & 15 & 30 & 45 & 60 & 75 & 90 & & \\
\hline & & & & \multicolumn{4}{|l|}{ Taste } & & \\
\hline $\mathrm{T}_{1}$ & 8.3 & 8.0 & 7.8 & 7.5 & 7.2 & 6.7 & 6.2 & 25.30 & $7.39 \mathrm{a}$ \\
\hline $\mathrm{T}_{2}$ & 8.1 & 7.8 & 7.4 & 6.9 & 6.4 & 6.0 & 5.3 & 34.57 & $6.84 b$ \\
\hline $\mathrm{T}_{3}$ & 8.0 & 7.7 & 7.4 & 7.1 & 6.6 & 6.1 & 5.4 & 32.50 & $6.90 \mathrm{~b}$ \\
\hline $\mathrm{T}_{4}$ & 8.2 & 7.9 & 7.7 & 7.4 & 7.1 & 6.6 & 6.1 & 25.61 & $7.29 \mathrm{a}$ \\
\hline $\mathrm{T}_{5}$ & 7.6 & 7.3 & 6.9 & 6.5 & 6.1 & 5.6 & 4.9 & 35.53 & $6.41 \mathrm{c}$ \\
\hline Mean & $8.04 a$ & $7.74 b$ & $7.44 \mathrm{c}$ & $7.08 \mathrm{~d}$ & $6.68 \mathrm{e}$ & $6.2 \mathrm{f}$ & $5.58 \mathrm{~g}$ & & \\
\hline
\end{tabular}

Values with different letters are significantly $(\mathrm{P}<0.05)$ different from each other.

Table 9. Effect of storage interval on the colour of fig fruit jam blended with apple pulp

\begin{tabular}{|c|c|c|c|c|c|c|c|c|c|}
\hline \multirow[t]{3}{*}{ Treat } & & \multicolumn{6}{|c|}{ Storage interval } & \multirow[t]{3}{*}{$\%$ Dec. } & \multirow[t]{3}{*}{ Mean } \\
\hline & 0 & 15 & 30 & 45 & 60 & 75 & 90 & & \\
\hline & & & & \multicolumn{4}{|c|}{ Colour } & & \\
\hline $\mathrm{T}_{1}$ & 7.9 & 7.6 & 7.3 & 7 & 6.7 & 6.3 & 5.8 & 26.58 & $6.94 \mathrm{a}$ \\
\hline $\mathrm{T}_{2}$ & 7.5 & 7.2 & 6.9 & 6.5 & 6.1 & 5.6 & 4.9 & 34.67 & $6.39 \mathrm{c}$ \\
\hline $\mathrm{T}_{3}$ & 7.5 & 7.2 & 6.9 & 6.6 & 6.2 & 5.9 & 5.2 & 30.67 & $6.50 \mathrm{c}$ \\
\hline $\mathrm{T}_{4}$ & 7.7 & 7.4 & 7.2 & 6.9 & 6.5 & 6.1 & 5.6 & 27.27 & $6.77 \mathrm{~b}$ \\
\hline $\mathrm{T}_{5}$ & 6.9 & 6.6 & 6.3 & 5.9 & 5.4 & 4.8 & 4.3 & 37.68 & $5.74 d$ \\
\hline Mean & $7.5 \mathrm{a}$ & $7.2 \mathrm{~b}$ & $6.92 \mathrm{c}$ & $6.58 \mathrm{~d}$ & $6.18 \mathrm{e}$ & $5.74 \mathrm{f}$ & $5.16 \mathrm{~g}$ & & \\
\hline
\end{tabular}

Values with different letters are significantly $(\mathrm{P}<0.05)$ different from each other.

Table 10. Effect of storage interval on the Texture of fig fruit jam blended with apple pulp

\begin{tabular}{|c|c|c|c|c|c|c|c|c|c|}
\hline \multirow{3}{*}{ Treat } & \multirow[b]{2}{*}{0} & \multicolumn{6}{|c|}{ Storage interval } & \multirow{3}{*}{$\%$ Dec. } & \multirow{3}{*}{ Mean } \\
\hline & & 15 & 30 & 45 & 60 & 75 & 90 & & \\
\hline & & & & \multicolumn{4}{|c|}{ Texture } & & \\
\hline $\mathrm{T}_{1}$ & 7.8 & 7.6 & 7.3 & 7.0 & 6.7 & 6.3 & 5.9 & 24.36 & $6.94 \mathrm{a}$ \\
\hline $\mathrm{T}_{2}$ & 7.4 & 7.1 & 6.8 & 6.4 & 5.9 & 5.4 & 4.9 & 33.78 & $6.27 \mathrm{c}$ \\
\hline $\mathrm{T}_{3}$ & 7.5 & 7.2 & 6.6 & 6.6 & 6.2 & 5.7 & 5.2 & 30.67 & $6.43 c$ \\
\hline $\mathrm{T}_{4}$ & 7.6 & 7.4 & 7.1 & 6.8 & 6.5 & 6.1 & 5.7 & 25.00 & $6.74 b$ \\
\hline $\mathrm{T}_{5}$ & 7.0 & 6.7 & 6.4 & 6.0 & 5.5 & 4.9 & 4.2 & 40.00 & $5.81 \mathrm{~d}$ \\
\hline Mean & $7.46 \mathrm{a}$ & $7.2 \mathrm{~b}$ & $6.84 \mathrm{c}$ & $6.56 \mathrm{~d}$ & $6.16 \mathrm{e}$ & $5.68 \mathrm{f}$ & $5.18 \mathrm{~g}$ & & \\
\hline
\end{tabular}

Values with different letters are significantly $(\mathrm{P}<0.05)$ different from each other.

(6.94) and minimum mean data was recorded for $\mathrm{T}_{5}$ (5.81). In case of percent decrease maximum decrease was recorded for $\mathrm{T}_{5}(40.00 \%)$ and minimum decrease was recorded for $\mathrm{T}(24.36 \%)$. Similar result was also noted by Chavan and Shaik (2015) in the texture of guava leather. At ambient temperature the decrease in texture ranged from 8.27 to 7.56 while at refrigerated temperature it was recorded as 8.27 to 7.80 . The textual properties of the jam are usually attributed pectic bodies composition. The pectic bodies in fig fruit are very low as compared to apple fruit. The decrease in pectic substance with storage significantly affect the texture score of the apple fig fruit blended jam. Islam et al., (2012) also observed change in the textural attributes were statistically significantly different among the strawberry jams and jelly. 
Table 11. Effect of storage interval on the overall acceptability of fig fruit jam blended with apple pulp

\begin{tabular}{|c|c|c|c|c|c|c|c|c|c|}
\hline \multirow{3}{*}{ Treat } & \multicolumn{7}{|c|}{ Storage interval } & \multirow[t]{3}{*}{$\%$ Dec. } & \multirow[t]{3}{*}{ Mean } \\
\hline & 0 & 15 & 30 & 45 & 60 & 75 & 90 & & \\
\hline & \multicolumn{7}{|c|}{ Overall acceptability } & & \\
\hline $\mathrm{T}_{1}$ & 8.2 & 7.9 & 7.7 & 7.4 & 7.1 & 6.5 & 6.2 & 24.39 & $7.29 \mathrm{a}$ \\
\hline $\mathrm{T}_{2}$ & 7.7 & 7.4 & 7.1 & 6.6 & 6.1 & 5.6 & 5.2 & 32.47 & $6.53 c$ \\
\hline $\mathrm{T}_{3}$ & 7.9 & 7.6 & 7.3 & 6.9 & 6.5 & 6.1 & 5.8 & 26.58 & $6.87 \mathrm{~b}$ \\
\hline $\mathrm{T}_{4}$ & 8.1 & 7.8 & 7.6 & 7.3 & 7.0 & 6.6 & 6.2 & 23.46 & $7.23 \mathrm{a}$ \\
\hline $\mathrm{T}_{5}$ & 7.1 & 6.8 & 6.4 & 6.0 & 5.5 & 4.9 & 4.3 & 39.44 & $5.86 \mathrm{~d}$ \\
\hline Mean & $7.8 \mathrm{a}$ & $7.5 b$ & $7.22 \mathrm{c}$ & $6.84 d$ & $6.44 \mathrm{e}$ & $5.94 \mathrm{f}$ & $5.54 \mathrm{~g}$ & & \\
\hline
\end{tabular}

Values with different letters are significantly $(\mathrm{P}<0.05)$ different from each other.

Overall acceptability. The overall acceptability of fig fruit jam blended with apple pulp was affected significantly $(\mathrm{P}<0.05)$ during storage (Table 11). Maximum mean data was recorded for $T_{1}(7.29)$ and minimum mean data was recorded for $\mathrm{T}_{5}(5.86)$. In case of percent decrease maximum decrease was recorded for $\mathrm{T}_{5}(39.44 \%)$ and minimum decrease was recorded for $\mathrm{T}_{4}(23.46 \%)$. The apple fig fruit blended jam remains acceptable after 90 days of storage period. Sensory traits are non-generally inter related and contributes independently towards the overall sensory perception. Results are presented in Table 11. These results are in accordance with Ehsan et al. (2003) reported decreasing trend from 8.80 to 7.96 in apple marmalade.

\section{Conclusion}

The objective of the research work was to prepare a value-added product from fig fruit jam blended with apple pulp in different concentration. The resulted data showed that changes in chemical nature of the jam effect the quality attributes. The sample showed significant response to the treatment but the temperature dependent of color changes and vitamin $\mathrm{C}$ losses were observed after 15 days of storage interval. The changes in colour was due to the Millard reaction during cooking. It is concluded from the present research treatment $\mathrm{T}_{1}$ (200:200) followed by $T_{2}(250: 150)$ was found best among the other treatment.

Conflict of Interest. The authors declare no conflict of interest

\section{References}

Ali, M. 2004. Canning of fruits vegetables and their juices, Effect of canning and storage on the quality of juice from different varieties of oranges. M.Sc Thesis, 59 pp., University of Faisalabad, Punjab, Pakistan.

Anjum, F.M., Din, M., Ahmad, I., Pasha, A. 2000. Preparation and evaluation of dried apricot diet jam. Pakistan Journal of Food Science, 3: 21-24.

AOAC, 2012. Official Methods of Analysis of AOAC International, $19^{\text {th }}$ edition, volume II. Association of Official Analytical Chemists. Gaithersburg, Maryland 20877-2417, USA.

Ayub, M., Ullah, J., Muhammad, A., Zeb, A. 2010. Evaluation of strawberry juice preserved with chemical preservatives at refrigeration temperature. International Journal of Nutrition and Metabolism, 2: 027-032.

Baker, R.A., Berry, N., Hui, Y.H., Barret, D.M. 2001. Food Preserves and Jams. $2^{\text {nd }} \mathrm{ed}, \mathrm{p} 2,3, \mathrm{CRC}$ press, Boca Raton, FL, USA.

Bokhari, S.A.A. 2002. The sweet gold of Pakistan. Export Promotion Bureau of Pakistan.

Chavan, U. D., Shaik, J. B. 2015. Standardization and preparation of guava leather. International Journal of Advanced Research in Biological Science, 2: 102-113.

Codex, A.C. 2009. Codex Standard for Jams, Jellies and Marmalades. Codex Stan 296, Codex Alimentarius Commission, Rome, Italy.

Ehsan, H.B., Naeem, Z.P., Javeed, A., Nazir, A. 2003. Development, standardization and storage studies on grape fruit apple marmalade. Pakistan Journal of Food Sciences, 13: 11-15.

Ehsan, E.B., Naeem, Z.P., Ghafoor, A., Bahtti, M.S. 2002. Development, standardization and 295 storage studies on watermelon lemon jam. Pakistan Journal of Food Sciences, 12: 296 21-24.

Hussain, I., Zeb, A., Shakir, I., Shah, A. S. 2008. 
Combined effect of potassium sorbate and sodium benzoate on individual and blended juices of apricot and apple fruits grown in Azad Jammu and Kashmir. Pakistan Journal of Nutrition, 7: 181-185.

Hussain, T. 2001. Food Composition Table for Pakistan. Government of Pakistan, Ministry of Planning and Development, Islamabad, Pakistan.

Islam, M.Z., Monalisa, K., Hoque, M. M. 2012. Effect of pectin on the processing and preservation of strawberry (Fragaria ananassa) jam and jelly. International Journal of Natural Sciences, 2: 08-14

Jawaheer, B., Goburdhun, D., Ruggoo, A. 2003. Effect of Processing and Storage of Guava into Jam and Juice on the Ascorbic Acid Content Plant Foods for Human Nutrition, Kluwer Academic Publishers. 58: $1-12$.

Larmond, E. 1977. Laboratory Methods of Sensory Evaluation of Foods, Department of Agriculture, 1673: 19-63, Canada,

Lee, S.K., Kader, A.A. 2000. Preharvest and postharvest factors influencing vitamin $\mathrm{C}$ content of horticultural crops. Postharvest Biology and Technology, 20: 207-220.

MINFAL, 2014-15. Agricultural Statistic of Pakistan, 45 pp. Ministry of Food, Agriculture and Livestock, Government of Pakistan, Islamabad.

Naikwadi P.M., Chavan, U.D., Pawar, V.D., Amarowicz, R. 2010. Studies on dehydration of figs using different sugar syrup treatments. Journal of Food Science and Technology, 47: 442-445.

PARC. 2018. Pakistan Agriculture Research Council. Fruit Crops Program. Retrieved October 25, 2018 from http://www.parc.gov.pk/index.php/en/faqy/119narc/hri/fcp

Pasman, W.J., Saris, W. H., Wauters, M.A. 1997. Effect of one-week fibre supplementation and satiety ratings and energy intake. Appetite, 29: 77-87.

Rojas, A.M., Gerschenson, L. N. 2001. Ascorbic acid destruction in aqueous model systems: an additional discussion. Journal of the Science of Food and Agriculture, 81: 1433-1439.

Ruiz-Nieto, A., Lopez, A.J. M., Lopez, M.R., Lopez, M.J., Medina, J.J., Scheer, H.A.T., Lieten, F., Dijkstra, J. 1997. Analysis of sucrose's from strawberry cultivars of commercial interest-contents evolution. In: Proceedings of the Third International Strawberry Symposium,439 (pp. 663-667), Veldhoven, Netherlands.

Shah, W., Khan, A., Zeb, A., Khan, M.A., Shah, F.N., Amin, N.U., Ayub, M. Wahab, S., Muhammad, A, Khan, S. H. 2015. Quality evaluation and preparation of apple and olive fruit blended jam. Global Journal of Medical Research, 15: 1-8.

Steel, R.G.D., Torrie, J.H. 1986. Principles and Procedures of Statistics. A Biometrical approach, $3^{\text {rd }}$ edition, McGraw Hill book Co. New York, USA.

Stover, E., Aradhya, M., Crisosto, C.H., Ferguson, L. 2007. Overview of the California fig industry and new interest in varieties for fresh fruit. In: Proceedings of the California Plant and Soil Conference, pp 169-175, ASA, Sacramento, USA.

Wong, M., Stanton, D.W., Burns, D.J. W. 1992. Effect of initial oxidation on ascorbic acid browning in stored kiwifruit juice and model concentrates. Food Science and Technology, 25: 574-578. 